\title{
Questionnaire for Assessing Design Practices
}

\author{
Steeve Gendron ${ }^{1}$, Jean Brousseau ${ }^{2}$, Abderrazak Elouafi $^{2}$ and Bruno Urli ${ }^{1}$ \\ ${ }^{1}$ Department of Management Sciences \\ ${ }^{2}$ Department of Mathematics, Informatics and Engineering \\ Université du Québec à Rimouski (UQAR), Rimouski, QC (Canada)
}

\begin{abstract}
In 2010, an exploratory survey on methods, tools and design techniques (MTT) has led to a better understanding of design practices of small and medium enterprises (SMEs) located in Eastern Quebec. The results of this survey have shown that most companies report having a structured design process, while only some resort to MTT. Following this study, a new research was launched to develop performance indicators for the design process, but also, and more generally, for design projects. To do this, a tool was developed to characterize and evaluate the design practices of companies as a way to establish performance indicators following a longitudinal study.

A questionnaire was developed as a tool based on a model of design system consisting of six dimensions (human, management, environment, product, process and techno-scientific). In the questionnaire, each dimension is characterized by different descriptors which are analyzed by four aspects that measure: i) if the descriptors are taken into consideration (the occurrence of the descriptors), ii) the importance of the descriptors according to the project success, iii) the company's performance level related on the descriptors and iv) the involvement of partners. For validation purposes, the tool was tested on a pilot basis by eight companies.

This paper introduces the questionnaire and the model that directed its construction and the types of analysis that can be conducted using the data collected.
\end{abstract}

Keywords: Design practices, design process, design system, performance, assessment tool.

\section{INTRODUCTION}

The project of a longitudinal study in order to develop performance indicators for design practices follows an exploratory study conducted in 2010 [5]. The results of this study show that a majority of respondents report using a structured design process (60\%) while only $27 \%$ (including the largest companies) resort to methods, specialized tools and design techniques (MTT). Since the design process benefits from the use of MTT, these results suggest that many SMEs design processes are not as structured as they could be.

The development of a tool for evaluating design performance comes in a context where companies must optimize their technology and manufacturing process but also their design methods [22]. Also, good design practices are key factors for innovation and business competitiveness [2][19].

The following sections present a questionnaire developed to serve as an investigative tool to an observatory that will be mandated to identify and monitor changes in design practices and to develop assessment tools and interventions for improving practices. This questionnaire was designed in electronic format and posted on the website Survey Monkey. Eight companies took part in its validation.

Specifically, the following sections discuss the conceptual model used to build the questionnaire and present the descriptors choice and control variables with their statements and their assessment scales. Some examples from the pilot validation of the questionnaire illustrate how the tool can be used to characterize design practices and to conduct a self-evaluation of the design system performance. Finally, the creation of an observatory for design practices is discussed.

\section{THE CONCEPTUAL MODEL}

The conceptual model that directed the completion of the questionnaire is presented in Figure 1. It shows the six dimensions (axes and aspects) and the interactions that define the design system. This model, inspired by Robin [16], is a synthesis of models of project description [4][8][12].

In this model, the environmental axis represents the company (structure, functions, physical and financial capabilities...) and its environment (competitors, subcontractors, market, customers, society...) [23].

The human axis is represented by the human resources involved in the project (responsibilities, availability, skills, psychological, evaluation of player...) [23]. 
As for the techno-scientific axis, it corresponds to knowledge and technologies already in place in the company.

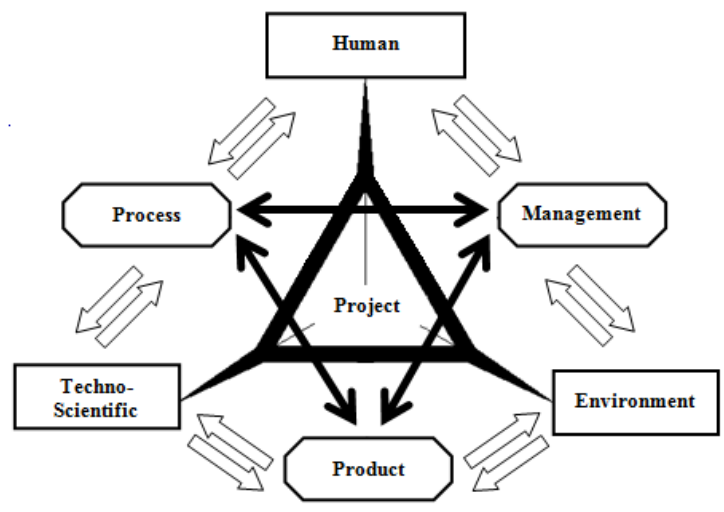

Fig 1. Design system.

To capture the relationship between the axes of the design system, it is proposed to apprehend them by intermediate aspects.

The product aspect is located between the environmental and techno-scientific axes because it is by its product that a company demonstrates its expertise and performs on the market [23].

The process aspect is located between the technoscientific and human axes because it is through the process (phases and activities) that the design team turns knowledge into a product [23].

The management aspect is located between the environmental and human axes because the management of the design project is reflected by the allocation of human and material resources and by establishing an appropriate organizational structure [23].

Considering the interactions between the axes and the aspects, it should be noted that the positioning of intermediate aspects is not fixed and can be located differently.

\section{THE QUESTIONNAIRE}

\subsection{Descriptors of Design Practices}

The questionnaire is built to reveal the practices in use among companies. Descriptors that correspond either to activities, technologies, methods or motives of investment in design allow characterizing each axis and aspect. This section discusses how these descriptors were defined.
3.1.1 Descriptors Related to Design Activities. Several descriptors (29 of 52 in total) are drawn from ontology of design activities [18] developed from various sources.

Tables 1, 2 and 3 present the different categories of activities covered by the ontology and the items that were derived to define the descriptors.

Table 1. Definition activities and questionnaire items.

\begin{tabular}{|l|l|}
\hline \multicolumn{1}{|c|}{ Definition activities } & \multicolumn{1}{c|}{ Questionnaire Items } \\
\hline Abstracting & \\
{$[8][14][21][24]$} & \\
Associating & \\
{$[8][14][15]$} & (3) Solutions generation \\
Combining & {$[14][15][21][24][25]$} \\
Generating & \\
{$[8][14][15][21][24][25]$} & \\
\hline Decomposing & $\begin{array}{l}\text { (1) Decomposition of the } \\
\text { problem }\end{array}$ \\
\hline 8$][14][21][24][25]$ & (4) Creating a \\
& nomenclature \\
\hline $\begin{array}{l}\text { Defining } \\
{[8][14][15][25]}\end{array}$ & (2) Define specifications \\
\hline Detailing [8] [25] & $\begin{array}{l}\text { (8) Documentation for } \\
\text { manufacturing }\end{array}$ \\
\hline $\begin{array}{l}\text { Standardizing } \\
{[8][14][15][25]}\end{array}$ & (6) Standardization \\
\hline $\begin{array}{l}\text { Structuring/Integrating } \\
{[8][25]}\end{array}$ & $\begin{array}{l}\text { (5) Choice of architecture } \\
\text { (7) Benchmarking }\end{array}$ \\
\hline $\begin{array}{l}\text { Synthesizing } \\
{[8][14][15][21][24][25]}\end{array}$ & (9) Final Report \\
\hline
\end{tabular}

Table 2. Evaluation activities and questionnaire items.

\begin{tabular}{|l|l|}
\hline \multicolumn{1}{|c|}{ Evaluation Activities } & \multicolumn{1}{c|}{ Questionnaire Items } \\
\hline $\begin{array}{l}\text { Analyzing } \\
{[8][14][15][21][24][25]}\end{array}$ & (4) Analyzing \\
\hline $\begin{array}{l}\text { Decision making } \\
{[8][14][15][21][25]} \\
\text { Selecting } \\
{[8][14][24][25]}\end{array}$ & (7) Solutions selection \\
\hline $\begin{array}{l}\text { Evaluating } \\
{[8][14][15][21][25]}\end{array}$ & (6) Performance estimation \\
\hline $\begin{array}{l}\text { Modeling } \\
{[8][14][15][24]}\end{array}$ & $\begin{array}{l}\text { (1) CAD } \\
\text { (2) Rapid Prototyping } \\
\text { (3) CAM }\end{array}$ \\
\hline Simulating [8][24] & (5) Simulating \\
\hline $\begin{array}{l}\text { Trying/Experimenting } \\
{[8][14][15][25]}\end{array}$ & $\begin{array}{l}\text { (8) Partial prototype } \\
\text { (9) Complete prototype }\end{array}$ \\
\hline
\end{tabular}


Table 3. Management activities and questionnaire items.

\begin{tabular}{|l|l|}
\hline \multicolumn{1}{|c|}{$\begin{array}{c}\text { Management } \\
\text { activities }\end{array}$} & \multicolumn{1}{c|}{ Questionnaire Items } \\
\hline $\begin{array}{l}\text { Constraining [14] } \\
\text { Identifying } \\
\text { [8][14][15][21] }\end{array}$ & (1) Feasibility study \\
\hline Exploring [16] & (2) Exploring solutions \\
\hline $\begin{array}{l}\text { Gather information } \\
{[8][14][15][24][25]}\end{array}$ & (3) Technology watch \\
\hline Planning [24] & $\begin{array}{l}\text { (6) Tasks Planning } \\
\text { (7) Resource Planning }\end{array}$ \\
\hline Prioritizing [3] & (9) Prioritization of objectives \\
\hline Solving [1][13] & $\begin{array}{l}\text { (10) Detection and resolution } \\
\text { of conflicts }\end{array}$ \\
\hline $\begin{array}{l}\text { Establishing } \\
\text { schedule [14][15] }\end{array}$ & (8) Scheduling and monitoring \\
\hline $\begin{array}{l}\text { Selecting } \\
{[8][14][15][24][25]}\end{array}$ & (11) Decision criteria \\
\hline $\begin{array}{l}\text { Searching } \\
{[8][14][24][25]}\end{array}$ & $\begin{array}{l}\text { (4) Internal research } \\
\text { (5) External research }\end{array}$ \\
\hline
\end{tabular}

The items were defined either by associating related activities or by subdividing too abstract activities. For example, in Table 1, the questionnaire item "solutions generation" does not differentiate between activities that are closely linked to "generating" like "abstracting", "associating" and "combining". Another example is the activity "decomposing" for which two items were formulated from the activity description ("decomposition of the problem" and "creating a nomenclature").

Descriptors related to the items of tables 1, 2 and 3 are presented in tables 4,5 and 6 of section 3.2. The connection between items and descriptors can be done through the numbers in brackets.

3.1.2 Other descriptors. Other descriptors were included in the questionnaire to highlight the major motivations of design projects (4 descriptors), the use of particular methods (12 descriptors) as well as characteristics related to organization of design teams (5 descriptors) and the use of leading practices ( 2 descriptors). The details of those descriptors are presented in next section

\subsection{Descriptors and Dimensions of the Model}

The following sections show the design system dimensions and the descriptors that have been assigned.

3.2.1 Process aspect descriptors. The process descriptors, presented in Table 4 , are derived from the definition activities (see Table 1).
Table 4. Process aspect descriptors.

(1) Decomposition of the problem (as modules, functions, energies, resources, requirements, etc.) (2) Define specifications (according to the needs, constraints, requirements, etc.)

(3) Solutions generation (by the use of methods such as brainstorming, TRIZ, etc.)

(4) Creating a nomenclature (for systems, functions, resources, dependencies links, etc.).

(5) Choice of architecture (modular, integrated or hybrid architecture for integration of functions)

(6) Standardization (reduce number of parts and components)

(7) Benchmarking of similar products (regarding to components, relationships between systems, etc.)

(8) Documentation for manufacture (detailed plans, specifications, assembly procedures, etc.)

(9) Summary documentation (final report)

These descriptors are committed to probe the activities that shape the product so that it fills specific functions until all the details required for the production are determined [18].

It should be noted that this categorization is not intended to restrict the design process to the definition activities since the design process can be defined as a set of phases or activities arranged in sequential or parallel manner in order to achieve an object that meets the requirements [16]. Thus, other descriptors inspired by the ontology can be integrated to the design process although these characterize other dimensions of the model.

3.2.2 Techno-scientific axis descriptors. Descriptors of Techno-scientific axis, presented in Table 5, correspond to the evaluation activities of Table 2 .

Table 5. Techno-scientific axis descriptors.

(1) Computer aided design (CAD software for virtual product development)

(2) Rapid Prototyping (3D physical model directly obtained from a CAD file)

(3) Integration of design and computer aided manufacturing (CAM)

(4) Analysis (formulating, analyzing and solving complex engineering problems)

(5) Simulation (imitate behavior or expected properties)

(6) Performance estimation (for solutions selection)

(7) Solutions selection (e.g. by the use of decision matrices)

(8) Partial physical prototypes

(9) Complete physical prototypes 
The descriptors assigned to this axis assess those activities requiring specialized knowledge assets reducing the room allocated for applicable solutions [18].

3.2.3 Management aspect descriptors. Management descriptors are presented in Table 6 and correspond, with some exceptions, to those of Table 3 . These descriptors are related to the coordination of the design project.

Table 6. Management aspect descriptors

(1) Feasibility study

(2) Exploring solutions with the customer (meetings, communication between the design team and clients)

(3) Technological watch (inventory of knowledge that can advance projects)

(4) Internal research (use of organizational memory, past design projects)

(5) External research (experts, interviews, patents, literature)

(6) Making tasks division and scheduling the design activities

(7) Resource planning (human, material, financial) based on activities

(8) Establishment of timelines and follow-up (on the basis of determining the critical path)

(9) Prioritization of objectives (determining an hierarchical order)

(10) Detection and conflict resolution (cognitive, communicative, interests, views, etc.)

(11) Decision criteria (predefined by go / no go, risk management, etc.)

(12) Concurrent engineering (design, manufacture, production and other development activities)

(13) E-based design (Product Data Management (PDM) or other)

Two descriptors, which are advanced practices [2], were added to those from the ontology to assess the workflow and the data management. These descriptors are "concurrent engineering" and "e-based design".

3.2.4 Product aspect descriptors. Table 7 shows the descriptors of the Product aspect. These descriptors correspond (although the list is not exhaustive) to different methods of Design for X or related methods. This approach was favoured because methods of Design for $\mathrm{X}$ are specifically oriented to maximize the requirements while reducing costs [2][7]. The use of these methods provides information on the orientation of the design to meet market expectations.
Table 7. Product aspect descriptors.

(1) Design for Assembly (DFA or other method)

(2) Design for Manufacturing (DFM or other method)

(3) Design for Maintenance (DFMA or other method)

(4) Design for Reliability (DFR or other method)

(5) Design for Safety (DFS or other method)

(6) For design services (DFS or other method)

(7) Lean design

(8) Design for Environment (DFE or other method)

(9) Design for Quality (DFQ or other method)

(10) Design for Production (DFP or other method)

(11) Design for Testability (DFT or other method)

(12) Alternative Design for X

3.2.5 Human axis Descriptors. The descriptors of the Human axis are shown in Table 8. These correspond to the organization of the design team (multidisciplinary team), to its composition (according to the skills, expertise, personality types), the arrangements put in place to support collaborative work as well as those set up to ensure the motivation of individuals involved in design projects [26].

Table 8. Human axis descriptors.

(1) Establishment of multidisciplinary design teams

(2) Formation of design teams based on skills and expertise

(3) Formation of design teams based on personality types

(4) Arrangements to support collaborative work (locals, meetings, communications, etc.)

(5) Arrangements to promote motivation (volunteering, bonuses, support to personal projects, etc.)

Considering that the design teams of SMEs are usually small, only a few descriptors were selected for this dimension. However, the results of the longitudinal study could lead to an increase in the number of descriptors for this dimension. For example, if it turns out that arrangements to promote collaboration and motivation are frequently put in place, it may become necessary to clarify these arrangements and assess other variables related to the mobilization of projects teams. For now, the evaluation of the questionnaire on a pilot basis failed to collect suggestions for other relevant descriptors of this dimension.

3.2.6 Environmental axis descriptors. The environmental axis assesses what motivates investment in product design. In North America, the main reasons to invest are changes in customer preferences and tighter time-to-market but one may also mention the growth of product performance and efficient development cost control for products and technology. 
Table 9. Environmental axis descriptors.

(1) Respond to changing customer preferences

(2) Tighten the time to market

(3) Increase product performance

(4) Cost control for product and technology

\subsection{Format of the Questionnaire and Evaluation}

The questionnaire is divided into three main sections, namely: i) identification of the company and the respondent, ii) characterization of the company (which includes the control variables) and iii) assessment of practices (by descriptors related to the dimensions of design system model).

The following sections describe the rating scales used to measure the descriptors as well as the control variables that will serve to establish categories of companies.

3.3.1 Descriptors evaluation. In the section of the questionnaire dedicated to the evaluation of practices, each dimension is introduced and it is asked to answer only for the descriptors that match the company's practices. The introduction of each dimension is followed by the corresponding list of descriptors (see section 3.2). For each descriptor, response options are proposed for four issues (facets). The evaluation is done through methodical response scales.

Table 10 offers a complete view of a descriptor's evaluation for the Techno-scientific dimension. It displays the introduction to the dimension, the terms of the primary descriptor of this dimension (see Table 5), and the questions and the choice of answers relevant to facets of the descriptor. The first facet assessed by the questionnaire concerns the occurrence of the descriptor (descriptors are taken into consideration during the design project). This point called "frequency of use" is also called "motive for investment in design" in the environmental dimension. This facet allows determining the specific design system of a company.

Because, according to various industries, practices and benefits attributed to design vary [2][17], it is important to know which descriptors are relevant to the surveyed company. For this reason, the second facet asks to rate the importance of each descriptor in relation to project success. This facet is called "importance for success".

The third aspect assessed by the questionnaire is the "performance" of the company on the descriptors because a descriptor can be considered very important but still need improvement.

Since some design activities can be assigned or delegated to partners, the fourth facet called "subcontracting and partnership" assesses the involvement of partners and subcontractors.
Table 10. Example of evaluation of a descriptor.

\begin{tabular}{|l|}
\multicolumn{1}{|c|}{ Techno-scientific axis } \\
Evaluate your organization regarding the descriptors in \\
relation with the use of technology or the use of \\
activities or practices that require specific knowledge in \\
your design projects. \\
Answer only those descriptors that match your tools \\
and activities. \\
(1) Computer aided design (CAD software for virtual \\
product development) \\
Do you use during your design projects? \\
0) Never 1) Rarely 2) Sometimes \\
3) Often 4) Always \\
What is the importance of this descriptor in relation to \\
the project's success? \\
0) Non-significant 1) Not important 2) Significant \\
3) Very important 4) Essential \\
How do you rate your performance in this area? \\
0) Not applicable 1) Poor 2) Weak \\
3) Good 4) Excellent \\
3) Very important 4) Essential
\end{tabular}

\subsection{The Control Variables}

In the questionnaire, the company categorization section includes a set of control variables. These variables are listed in Table 11.

Table 11. Control variables.

\begin{tabular}{|l|l|}
\hline $\begin{array}{l}\text { 1- Number of } \\
\text { employees }\end{array}$ & $\begin{array}{l}\text { 8- Level of technological } \\
\text { uncertainty }\end{array}$ \\
\hline 2- Turnover & $\begin{array}{l}\text { 9- Proportion of new } \\
\text { products }\end{array}$ \\
\hline 3- Business growth & $\begin{array}{l}\text { 10- Partnerships } \\
\text { developed }\end{array}$ \\
\hline $\begin{array}{l}\text { 4- Main business } \\
\text { activity }\end{array}$ & $\begin{array}{l}\text { 11- Size of the design } \\
\text { team }\end{array}$ \\
\hline $\begin{array}{l}\text { 5- Description of } \\
\text { business activity }\end{array}$ & $\begin{array}{l}\text { 12- Number of engineers } \\
\text { in the design team }\end{array}$ \\
\hline 6- Product Types & 13- Use of the CAD \\
\hline 7- Complexity & $\begin{array}{l}\text { 14- Difficulty in } \\
\text { recruiting }\end{array}$ \\
\hline
\end{tabular}


These variables will allow identifying practices that contribute the most to the success of projects for certain categories of companies.

More specifically, the variables "number of employees" and "turnover" are used to categorize the size of the company. For example, in Canada, SMEs have fewer than 500 employees with an annual turnover less than $\$ 50$ million. Table 14 presents the questions for these two variables and the response options.

Table 12. Number of employees and turnover.

\begin{tabular}{|c|l|}
\hline Control variables & \multicolumn{1}{|c|}{ Response options } \\
\hline \multirow{5}{*}{ 1- Number of employees } & $\circ 10$ or less \\
& $\circ 10$ to 25 \\
& $\circ 26$ to 50 \\
& $\circ 51$ to 100 \\
& $\circ 101$ to 250 \\
& $\circ 251$ to 500 \\
& $\circ$ More than 500 \\
& \\
\hline \multirow{5}{*}{ 2-Turnover } & $\circ$ Less than $\$ 0.1 \mathrm{M}$ \\
& $\circ \$ 0,1 \mathrm{M}$ to $\$ 0,5 \mathrm{M}$ \\
& $\circ \$ 0,5 \mathrm{M}$ to $\$ 1 \mathrm{M}$ \\
& $\circ \$ 1 \mathrm{M}$ to $\$ 3 \mathrm{M}$ \\
& $\circ \$ 3 \mathrm{M}$ to $\$ 5 \mathrm{M}$ \\
& $\circ \$ 5 \mathrm{M}$ to $\$ 10 \mathrm{M}$ \\
& $\circ \$ 10 \mathrm{M}$ to $\$ 25 \mathrm{M}$ \\
& $\circ \$ 25 \mathrm{M}$ to $\$ 50 \mathrm{M}$ \\
& $\circ \$ 50 \mathrm{M}$ to $\$ 100 \mathrm{M}$ \\
& $\circ \$ 100 \mathrm{M}$ to $\$ 250 \mathrm{M}$ \\
& $\circ \$ 250 \mathrm{M}$ to $\$ 1 \mathrm{G}$ \\
& $\circ \mathrm{M}$ ore than $\$ 1 \mathrm{G}$ \\
& \\
\hline
\end{tabular}

The variable "business growth" allows appreciating the success of the company on the market while the variable "proportion of new products" allows appreciating the dynamism in design. For example, for companies with best practices in new products development, nearly $50 \%$ of sales come from new products developed over the last five years [6]. Since the percentage of sales can be strategic information, it was decided to assess the proportion of new products offered by the company, a new product being defined as a product developed over the last five years.

Statements of issues related to "business growth" and "proportion of new products" with their evaluating scales are presented in Table 13.
Table 13. Business growth and proportion of new products.

\begin{tabular}{|l|l|}
\hline \multicolumn{1}{|c|}{ Control variables } & \multicolumn{1}{|c|}{ Response options } \\
\hline $\begin{array}{l}\text { 3- Business growth over } \\
\text { the past 5 years: }\end{array}$ & $\begin{array}{l}\circ \text { Decreasing } \\
\circ \text { Stable } \\
\circ \text { Slow growth } \\
\circ \text { Moderate growth } \\
\circ \text { Strong growth }\end{array}$ \\
\hline $\begin{array}{l}\text { 9- What is the proportion } \\
\text { of new products (goods, } \\
\text { processes, equipment) in } \\
\text { the range offered by your } \\
\text { company (products } \\
\text { developed or improved } \\
\text { during the last five years)? }\end{array}$ & $\circ 0$ \\
& $\circ 2 / 5$ \\
& $\circ 4 / 5$ \\
\end{tabular}

The variable "developed partnerships", presented in Table 14 identifies the types of partners involved in design projects. The response options offered for this question are not exclusive because a company may work with several types of partners. The choice of this control variable is justified by the fact that the product design often involves the collaboration of several partners pooling their expertise [11].

Table 14. Partnerships developed.

\begin{tabular}{|c|c|}
\hline Control variables & Response options \\
\hline $\begin{array}{l}\text { 10- Who are the } \\
\text { company's partners to } \\
\text { achieve the project } \\
\text { design? }\end{array}$ & $\begin{array}{l}\text { O Educational and research } \\
\text { institutions (universities, } \\
\text { colleges) } \\
\text { o Economic development } \\
\text { organizations } \\
\text { o Private societies } \\
\text { (consortium, firms, } \\
\text { associates) } \\
\text { o Preferred suppliers } \\
\text { (subcontractors) } \\
\text { o Customers }\end{array}$ \\
\hline
\end{tabular}

Two variables are used to distinguish the different economic activities in which businesses are engaged; first a classification based on NAICS sectors called "main economic activities" and a second that is an open question ("description of design projects"). The NAICS [20] is built on a principle of aggregation which includes production units that use similar production processes. Regarding the "description of design projects", this variable is used to validate that the proposed NAICS classification apply to the surveyed company while providing additional information. Table 15 presents these variables while the response options related to the "Main economic activities" are presented in Table 16. 
Table 15. Main economic activities and description of design projects.

\begin{tabular}{|l|l|}
\hline \multicolumn{1}{|c|}{ Control variables } & \multicolumn{1}{c|}{ Response options } \\
\hline $\begin{array}{l}\text { 4- Main economic } \\
\text { activities (only one } \\
\text { answer, depending on } \\
\text { your major business } \\
\text { sector: manufacture, } \\
\text { construction or } \\
\text { services): }\end{array}$ & $\begin{array}{l}\text { According to the NAICS } \\
\text { classification }\end{array}$ \\
\hline $\begin{array}{l}\text { Manufacturing (20 } \\
\text { choices) }\end{array}$ \\
$\begin{array}{l}\text { 5- Denstruction (3 choices) } \\
\text { project in about } 10 \\
\text { words: }\end{array}$
\end{tabular}

Manufacturing, Construction and Professional, scientific and technical services correspond to 3 of NAICS sectors while the response options correspond to their subsectors. Only NAICS sectors and subsectors considered most relevant in regard to design are offered as response options.

Table 16. Industries according to NAICS classification.

\begin{tabular}{|l|}
\hline \multicolumn{1}{|c|}{ Manufacturing } \\
\hline Food manufacturing \\
Beverage and tobacco products manufacturing \\
Textile mills \\
Textile products mills \\
Clothing manufacturing \\
Wood products manufacturing \\
Paper manufacturing \\
Printing and related support activities \\
Petroleum and coal products manufacturing \\
Plastics and rubber products manufacturing \\
Non-metallic mineral products manufacturing \\
Primary metals manufacturing \\
Metal products manufacturing \\
Machinery manufacturing \\
Computer and electronic products manufacturing \\
Electrical equipment, appliances and components \\
manufacturing \\
Transportation equipment manufacturing \\
Furniture and related products manufacturing \\
Miscellaneous manufacturing \\
\hline \multicolumn{1}{c|}{ Construction } \\
\hline Construction of buildings \\
Heavy and civil engineering construction \\
Specialty trade contractors \\
\hline Professional, scientific and technical services \\
\hline Professional, scientific and technical services \\
\hline
\end{tabular}

Products are categorized by three variables, the "types of products," the "complexity" (depending on the number of components) and the "level of technological uncertainty" [8]. Since business sectors are many, product characterization can be useful in discriminating between different patterns of design system that will be encountered. This approach may allow larger groupings than by economic activities. The variables are presented in Table 17.

Table 17. Product types, complexity and level of technological uncertainty.

\begin{tabular}{|c|c|}
\hline Control variables & Response options \\
\hline $\begin{array}{l}\text { 6- What type of } \\
\text { products are designed } \\
\text { by the company? }\end{array}$ & $\begin{array}{l}\text { O Industrial products } \\
\text { (processes, equipment, } \\
\text { components, materials, etc.) } \\
\text { o Mass consumption products } \\
\text { (ready for use, intended for } \\
\text { the general public) } \\
\text { o Not applicable }\end{array}$ \\
\hline $\begin{array}{l}\text { 7- Regarding the } \\
\text { number of components, } \\
\text { how are your designed } \\
\text { objects: }\end{array}$ & $\begin{array}{l}\text { o Simple (few components, e.g. } \\
\text { corkscrew) } \\
\text { o Complex (multiple } \\
\text { components, e.g. appliances) } \\
\text { O Very complex (many } \\
\text { components, e.g. airplanes, } \\
\text { buildings) }\end{array}$ \\
\hline $\begin{array}{l}8 \text { - What is the } \\
\text { uncertainty level related } \\
\text { to your designed } \\
\text { objects? }\end{array}$ & $\begin{array}{l}\text { Low (use of known and } \\
\text { proven technologies) } \\
\text { O Average (integration of } \\
\text { innovations leading to some } \\
\text { unknowns) } \\
\text { High (very innovative and } \\
\text { creative projects) } \\
\text { o Does not apply }\end{array}$ \\
\hline
\end{tabular}

The design teams are qualified by two variables, i.e. the "size of the design team" and the "number of engineers in the team." These variables are important because managing a large or a small team does not present the same challenges (organization, monitoring, etc.) and it is assumed that the presence of engineers in a team should be accompanied by the use and mastery of tools and methods related to their discipline. These variables are presented in Table 18.

Table 18. Team size and number of engineers.

\begin{tabular}{|l|l|}
\hline \multicolumn{1}{|c|}{ Control variables } & \multicolumn{1}{|c|}{ Response options } \\
\hline & $\circ$ No one \\
11- Usual size of a & $\circ 1$ to 3 \\
design team assigned to & $\circ 4$ to 10 \\
a project: & $\circ 11$ to 25 \\
& $\circ 26$ to 50 \\
& $\circ 51$ to 100 \\
& $\circ$ More than 100 \\
\hline & $\circ$ No one \\
& $\circ 1$ to 3 \\
12- Usual number of & $\circ 4$ to 10 \\
engineers in a design & $\circ 11$ to 25 \\
team: & $\circ 26$ to 50 \\
& $\circ 51$ to 100 \\
& $\circ$ More than 100 \\
\hline
\end{tabular}

CAD tools can be used for various purposes during design project [16] it is why a variable asks to specify the "Use of CAD". The last control variable concerns the 
"difficulty of hiring" skilled human resources in design, which is a matter of interest for a teaching and research chair. Table 19 shows these variables.

Table 19. Use of CAD and recruitment difficulties.

\begin{tabular}{|l|l|}
\hline \multicolumn{1}{|c|}{ Control variables } & \multicolumn{1}{c|}{ Response options } \\
\hline $\begin{array}{l}\text { 13- If you use computer } \\
\text { aided design tools } \\
\text { (CAD), for what } \\
\text { purpose are they used? }\end{array}$ & $\begin{array}{l}\text { ○ 3D Modeling (drawings) } \\
\text { o Simple analyzes (mass } \\
\text { movements, interference) } \\
\text { o Numerical analyzes (finite } \\
\text { element, dynamic analysis) }\end{array}$ \\
\hline $\begin{array}{l}\text { 14-Do you have any } \\
\text { difficulties in hiring } \\
\text { skilled human resources } \\
\text { in engineering design? }\end{array}$ & $\begin{array}{l}\text { ○ Yes } \\
\text { ○ No }\end{array}$ \\
\hline
\end{tabular}

\section{DATA PROCESSING}

The data collected through the assessment tool can be used for two purposes. First, based on the respondent's perception, the tool is designed to describe the design system as well as the company's performance. Thus, the results of a company can be used to report weaknesses or inconsistencies concerning the control of descriptors and help to initiate a reflection on improvement targets. In a second step, as part of a longitudinal study, data will be used to make depictions for the economic activities (or for other categories) to determine the descriptors that are most associated with projects' success, the purpose of this exercise being to situate a company regarding to the best practices of its class.

The following sections describe how the tool can be used in a perspective of self-evaluation of the design system performance and present the creation of an observatory of design practices whose mandate will be to conduct a longitudinal study.

\subsection{A tool to Describe the Design System and to Conduct Self-Evaluation}

The questionnaire allows describing a company's design system and to conduct a self-evaluation. To do this, the company identifies the most important descriptors (i.e. those that contribute most to the project's success) and evaluates its performance. A negative gap observed between scores of "importance for success" and the "performance" may be interpreted as an improvement target of greater or lesser priority depending on the magnitude of the gap and the importance level assigned.

Figure 2 and Figure 3 are drawn from the results obtained during the pilot validation of the questionnaire. Figure 2 illustrates the overall positioning of a company according to the six dimensions of the design system. In our case, the company is a foundry. Figure 2 shows that the design system of the company includes descriptors related to five out of six dimensions. The Product aspect is excluded since the different methods specified in the questionnaire are not used by this company.

The curves concerning "occurrence", "outsourcing" and "importance for success" in the different dimensions of the design system reveal fairly equal scores, although the descriptors of the Human dimension are considered slightly less important than the others. Finally, the "performance" curve is generally higher in all dimensions except in the Techno-scientific dimension where it is equal to others.

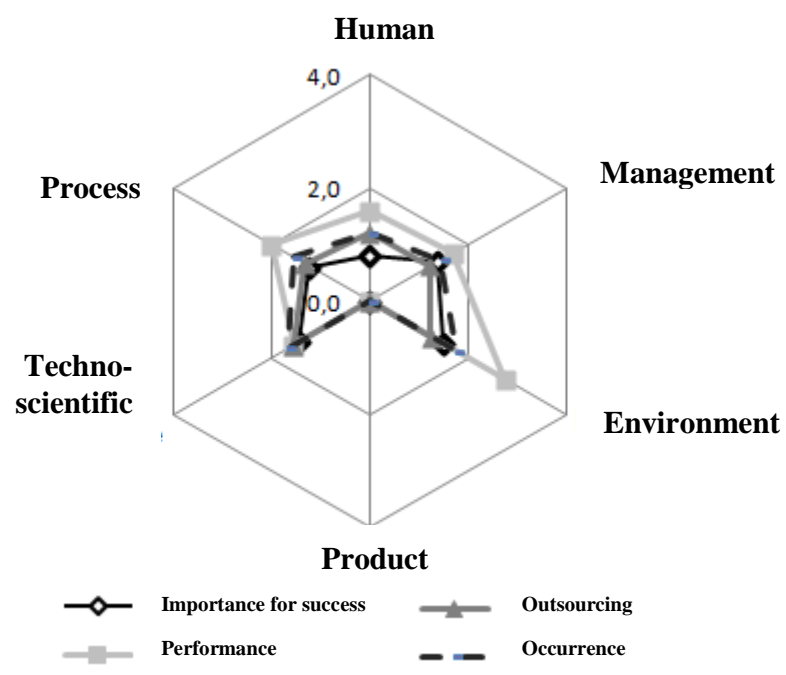

Fig 2. Positioning on the design system.

Figure 3 shows in more detail the Techno-scientific dimension and shows that 7 of the 9 proposed descriptors (see Table 5) are relevant for the company.

It is especially striking that the "CAD" is performed externally and that the "simulation" is considered of medium importance when this activity is neither performed nor outsourced. There is also a strong emphasis put on "analysis" activity. 


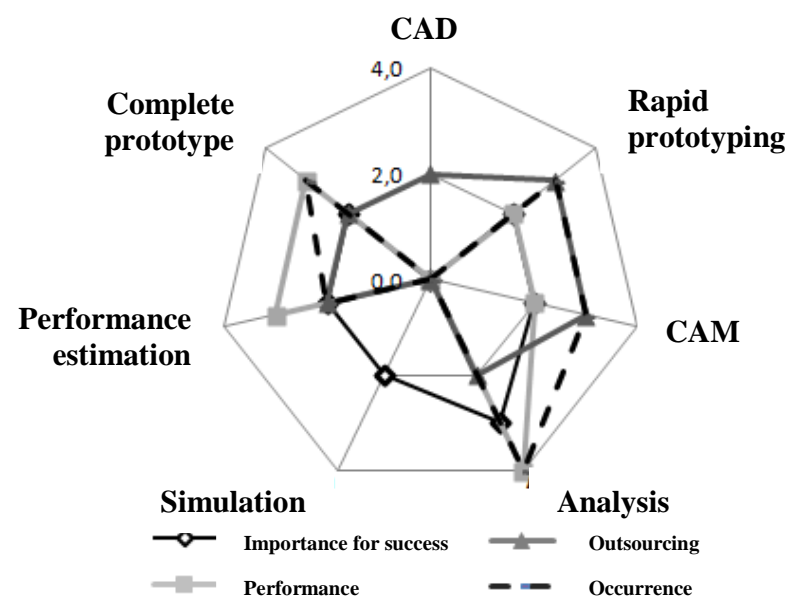

Fig 3. Positioning on the techno-scientific axis.

Based on the gap found between the "importance of the success" and "performance" curves, actions could be considered to increase the performance level of the "simulation" descriptor. Since the "simulation" is often linked with "CAD", this increase may be achieved by an internalization of the "CAD" activity. However, it is the company's responsibility to determine the appropriate actions and to ensure the consistency of these responses. A detailed analysis of various dimensions of the design system can lead to the identification of several targets.

It should be noted that since this is an assessment based on the respondent's perception, the results could vary within the same company depending on who responds. Also, an evaluation of the design system should probably take into account the views of several people involved in the projects. On a practical level, the fact that respondents can differ in evaluating descriptors may be symptomatic of some problems (understanding of expectations, of roles and responsibilities, communication problem, etc.) and may impact on the conduct of company projects. When performing the longitudinal study, the selection of respondents will be crucial. Ideally, respondents should be project managers or people deeply involved in design projects.

\subsection{An Observatory of Design Practices}

This questionnaire will serve as an investigative tool for an observatory of design practices that will be established to study and monitor changes in design practices especially in SMEs.

Data collected through a longitudinal study will improve knowledge of design practices in various categories of companies and will allow identifying the most important descriptors for the achievement of project success. With enough data, through factor analysis (principal components analysis), it will be possible to determine which are the most appropriate descriptors to describe design systems. The determination of these descriptors will help build performance indicators to compare companies and to establish diagnostics and recommendations.

\subsection{Conclusion}

In this paper, we presented a model of design system that inspired the development of an investigative tool for design practices. This tool permits to characterize design systems and to conduct a self-evaluation of the performance of a company compared to different descriptors. A longitudinal study based on this tool will lead to a better understanding of design practices especially for SMEs, and including the descriptors considered most important for achieving success with design projects.

Studying design systems and their performance can open a door to various interventions. For example, based on the questionnaire, it is conceivable to develop dashboards tailored to SMEs for the implementation and the monitoring of design projects. More simply, the tool can help formalize the design process in companies that have not yet carried out this exercise. Also, analysis of design systems will allow for a better knowledge of the strengths and weaknesses of companies (especially SMEs) and for the development of targeted programs to support and improve design practices.

\section{References}

[1] F.M.T. Brazier, P.H.G. van Langen, J. Treur, "Modelling conflict management in design: an explicit approach." A.I. Eng. Design Anal. Manuf., vol. 9:4, pp. 353-366, 1995.

[2] DESIGN EXCHANGE en collaboration avec Manufacturiers et exportateurs du Canada et Industrie Canada, "L'ÉTAT de la CONCEPTION DE PRODUITS: LE RAPPORT CANADIEN 2010”, 2010.

[3] A.H.B. Duffy, A.Persidis, K.J. MacCallum, "NODES: a numerical and object based modelling system for conceptual engineering design." Knowl.-based Syst., vol. 9:3, pp. 183-206, 1996.

[4] E. Eder, "Integration of theories to assist practice", 5th International Conference on Integrated Design and Manufacturing in Mechanical Engineering, IDMME04, Bath, 2004.

[5] S.Gendron, J.Brousseau, A. Elouafi, B. Urli, "Development of a Tool for Assessing the Design Process: A step toward the creation of a Design Observatory.," in Proc. CEEA Canadian Engineering Education Conf., CEEC11, Andy Fisher (ed.) (St. John's, NL; 6-8 June 2011), 7 pp., 2011. 
[6] A. Griffin, "PDMA Research on New Product Development Practices: Updating Trends and Benchmarking Best Practices.” J. Prod. Innov. Manag., vol. 14, pp. 429-458, 1997.

[7] G.Q. Huang, Design for X: concurrent engineering imperatives. New York: Springer, 1996, 489 pp.

[8] V. Hubka, Principles of engineering design. London: Butterworth Scientific, 1988, 128 pp.

[9] G. Javel, Organisation et Gestion de la Production Cours et exercices corrigés. Dunod, collection SciencesSup, 2010, 443 pp.

[10] H. Laurikkala, E. Puustinen, E. Pajarre, K. Tanskanen, "Reducing complexity of modelling in large delivery projects", 13th International Conference on Engineering Design, ICED01, Glasgow, 2001.

[11] J. Le Duigou "Cadre de modélisation pour les systèmes PLM en entreprise étendue : Application aux PME mécanicienne." Doctoral thesis, École Centrale de Nantes, École doctorales Science Pour l'Ingénieur, Géosciences, Architecture, 2010.

[12] F. Marle, "Modèles d'informations et méthodes pour aider à la prise de décision en management de projet" Thèse Ecole Centrale de Paris, 2002.

[13] V. Oh, J. Sharpe, "Conflict management in an interdisciplinary design environment." Artificial Intelligence for Engineering, Design, Analysis and Manufacturing, vol. 9. pp. 247-258, 1995.

[14] G. Pahl, and W. Beitz, Engineering Design - A Systematic Approach, New York: Springer, 1996, 644 pp.

[15] S. Pugh, Total design, integrated methods for successful product engineering, Addison-Wesley, 1991, 296 pp.

[16] V. Robin, "Évaluation de la performance des systèmes de conception pour la conduite de l'ingénierie des produits ; prototype logiciel d'aide aux acteurs", Thèse doctorale, Université Bordeaux 1, École des sciences doctorales des sciences physiques et de l'ingénieur, 2005.
[17] L. Raymond, J. St-Pierre, "La R\&D en tant que déterminant de l'innovation dans les PME : Essai de clarification empirique", Retour aux communications, $5^{\mathrm{e}}$ Congrès International de l'Académie de l'Entreprenariat, 2007.

[18] S.K. Sim, A.H.B. Duffy, "Towards an ontology of generic engineering design activities." Res. Eng. Design, vol. 14, pp. 200-223, 2003.

[19] Sisodia, "Competitive Advantage Through Design." Journal of Business Strategy, vol. 13:6, pp. 33-40, 1992.

[20] Statistics Canada, "North American Industry Classification System (NAICS) Canada." Catalogue no. 12501-X (2012)

[21] N.P. Suh, The principles of design. New York: Oxford University Press, 1990, 401 pp.

[22] J.C. Tarondeau, Stratégie Industrielle, Paris: Vuibert, 1998, 424 pp.

[23] G. Topliceanu G., V. Robin, C. Ispas, P. Girard, "Évaluation de la performance des processus collaboratifs en conception de produits", U.P.B. Sci. Bull., Series D, Vol. $\mathrm{N}^{\circ}$ 72, Iss. 3, 2010.

[24] D. Ullman, The Mechanical Design Process, New York: McGraw-Hill, Inc., NY, 1992, 337 pp.

[25] K.T. Ulrich, S.D. Eppinger, Product design and development, McGraw Hill International editions, 2000, (2nd ed.), $358 \mathrm{pp}$.

[26] R. Wittorski, Analyse du travail et production de compétences collectives. Editions L'Harmattan, 1997, 239 pp. 